\title{
The Key Role of Aptian-Albian Marine Fossils from Eastern Heilongjiang in Marine-Nonmarine Stratigraphic Correlation
}

\author{
Gang Li1 ${ }^{*}$, Peter Bengtson² \\ ${ }^{1}$ State Key Laboratory of Palaeobiology and Stratigraphy, Center for Excellence in Life and Palaeoenvironment, Nanjing Institute \\ of Geology and Palaeontology, Nanjing, China \\ ${ }^{2}$ Institute of Earth Sciences, Heidelberg University, Heidelberg, Germany \\ Email: gangli@nigpas.ac.cn
}

How to cite this paper: Li, G. and Bengtson, P. (2019) The Key Role of Aptian-Albian Marine Fossils from Eastern Heilongjiang in Marine-Nonmarine Stratigraphic Correlation. Open Journal of Geology, 9, 543-546.

https://doi.org/10.4236/ojg.2019.910037

Received: August 15, 2019

Accepted: September 17, 2019

Published: September 20, 2019

Copyright $\odot 2019$ by author(s) and Scientific Research Publishing Inc. This work is licensed under the Creative Commons Attribution International License (CC BY 4.0).

http://creativecommons.org/licenses/by/4.0/

\begin{abstract}
The alternating marine and nonmarine coal-bearing Lower Cretaceous successions are well developed in eastern Heilongjiang, northeastern China, including the Jixi Group in the west and the Longzhaogou Group in the east. The correlation of these two lithostratigraphic groups with the nonmarine Jehol Group is important for dating the exceptionally well-preserved Jehol Biota. The Early Cretaceous marine fossils recovered from eastern Heilongjiang include ammonites, bivalves, radiolarians, foraminifers and dinocysts. During the early Aptian transgression the ammonite fauna entered the Hulin and Mishan areas and the bivalve Aucellina fauna in the Jixi area. This enables correlation of the marine lower part of the Chengzihe Formation of the Jixi Group with the Qihulin Formation of the Longzhaogou Group.
\end{abstract}

\section{Keywords}

Lower Cretaceous, Aptian, Albian, Marine-Nonmarine Correlation, Marine Fossils, Eastern Heilongjiang, Northeastern China

\section{Introduction}

The upper Mesozoic deposits in China are mainly of nonmarine origin [1] [2]. The lack of index fossils makes it difficult to correlate precisely the nonmarine Cretaceous successions with the standard geological time scale. In particular, it is problematic to identify the nonmarine Jurassic-Cretaceous boundary [3], and to date the well-known Jehol Biota [4] [5]. In eastern Heilongjiang in northeastern China, an upper Lower Cretaceous succession of alternately marine and nonma- 
rine coal-bearing rocks is well-developed, comprising the Jixi Group in the west (in which component taxa of the Jehol Biota were recovered) and the Longzhaogou Group in the east [6]. Since the discovery of the first ammonite specimen in 1958 [7], the coal-bearing beds in eastern Heilongjiang have attracted the attention of the Chinese geologists, not only because of the economic value of the coal, but also owing to the difficulties of stratigraphic correlation of the nonmarine and marine beds.

\section{Marine Transgressions in Eastern Heilongjiang}

The Early Cretaceous transgressions introduced marine faunas into eastern Heilongjiang, thus providing opportunities to correlate the Jixi and Longzhaogou groups. During the early Aptian transgression, the seawater advanced from the eastern continental margin through a narrow bay across the Hulin and Mishan areas to the Jixi area. The lower Aptian marine beds of the lower part of the Chengzihe Formation (Jixi Group) have yielded an Aucellina (A.) caucasica-Filosina subovalis- Thracia rotundata assemblage [8]. The contemporaneous marine Qihulin Formation (Longzhaogou Group) has yielded the following macro- and micro-faunas: 1) a low-diversity ammonite fauna dominated by Pseudohaploceras? cf. nipponicum and Pseudohaploceras peideense, with subordinate Eogaudryceras (E.) cf. yunshanense [9]; 2) an abundant bivalve fauna containing Nuculana (Praesaccella) cf. yatsushiroensis, Filosina subovalis and Thracia rotundata [8]; 3) a low-diversity, poorly preserved radiolarian fauna containing Archaeodictyomitra sp., Novixitus sp. and Xitus sp. [10]; 4) a low-diversity agglutinated foraminifer fauna with Cribrostomoides nonioninoides, Haplophragmoides concavus and H. gigas minor [11].

The upper Aptian marine deposits of the upper part of the Yunshan Formation (Longzhaogou Group) are characterized by an Aucellina (Aucellina) caucasica- $A$. (A.) aptiensis-Filosina subovalis-Thracia rotundata bivalve assemblage, overlain by beds containg an Aucellina ( $A$.) cf. caucasica- $A$. $(A$.) cf. aptiensis bivalve assemblage and an Odontochitina operculata-esperopsis didaoensis dinocyst assemblage. The upper part of the Chengzihe Formation (Jixi Group) contains a marine Sinopsamobia ovalis-Filosina subovalis bivalve assemblage [8].

The Albian marine transgression introduced dinocysts to the Muling Formation (Jixi Group), which include the endemic taxa Circulodinium cingulatum and Sentusidinium sp., and the cosmopolitan species C. attadalicum, Palaeoperidinium cretaceum and Oligosphaeridium totum [8]. A contemporaneous marine Sinopsamobia ovalis bivalve fauna has been identified in the Zhushan Formation (Longzhaogou Group).

\section{Marine-Nonmarine Correlation}

The marine lower part of the Chengzihe Formation can be correlated with the Qihulin Formation through the early Aptian marine transgression that brought the ammonite fauna to the Hulin and Mishan areas and the bivalve Aucellina to 
the Jixi area [9]. The brackish-water bivalve Sphaerioides yixianensis (= Tetoria yixianensis) and the freshwater bivalves Arguniella cf. quadrata and Arguniella cf. ventricosa from the upper Chengzihe Formation provide direct correlation with the Shahai Formation of the Jehol Group in western Liaoning [9]. The overlying Fuxin Formation of the upper part of the Jehol Group can be correlated with the Muling Formation of the upper part of the Jixi Group, through a Sphaerium bivalve fauna contained in both formations.

\section{Acknowledgements}

The study was supported by the Strategic Priority Research Program of the Chinese Academy of Sciences (XDB26000000) and the National Natural Science Foundation of China $(41572006,41688103,41972007)$. This is a contribution to UNESCO-IUGS IGCP Project 679.

\section{Conflicts of Interest}

The authors declare no conflicts of interest regarding the publication of this paper.

\section{References}

[1] Li, G. and Matsuoka, A. (2012) Jurassic Clam Shrimp ("Conchostracan”) Faunas in China. Science Report of Niigata University (Geology), 27, 73-88. https://doi.org/10.1080/028418501127346846

[2] Xi, D.P., Wan, X.Q., Li., G.B. and Li, G. (2019) Cretaceous Integrative Stratigraphy and Timescale of China. Science China Earth Sciences, 62, 256-286. https://doi.org/10.1007/s11430-017-9262-y

[3] Li, G. and Matsuoka, A. (2015) Searching for a Non-Marine Jurassic/Cretaceous Boundary in Northeastern China. Journal of Geological Society of Japan, 121, 109-122. https://doi.org/10.5575/geosoc.2015.0001

[4] Chang, M.M., Chen, P.J., Wang, Y.Q., Wang, Y. and Miao, D.S. (2003) The Jehol Biota: The Emergence of Feathered Dinosaurs, Beaked Birds and Flowering Plants. Shanghai Scientific and Technical Publishers, Shanghai, 1-208.

[5] Zhou, Z.H., Barrett, P.M. and Hilton, J. (2003) An Exceptionally Preserved Lower Cretaceous Ecosystem. Nature, 421, 807-814. https://doi.org/10.1038/nature01420

[6] Li, G., Matsuoka, A., Yang, Q. and Sha, J.G. (2019) Middle and Late Jurassic Radiolarians from Nadanhada Terrane of Eastern Heilongjiang Province, Northeastern China. Paleontological Research, 23, In Press. http://www.palaeo-soc-japan.jp/publications/pr/2019PR006_Li_etal.pdf

[7] Huang, B.H. (1963) The Age of the Mesozoic Coal-Bearing Measures of the Northeastern Part of Northeast China. Chinese Science Bulletin, 9, 69-71. (In Chinese)

[8] Sha, J.G. (2007) Cretaceous Stratigraphy of Northeast China: Non-Marine and Marine Correlation. Cretaceous Research, 28, 146-170. https://doi.org/10.1016/j.cretres.2006.12.002

[9] Li, G. and Bengtson, P. (2018) Early Cretaceous Ammonites from Eastern Heilongjiang, Northeastern China, and Their Chronostratigraphical Significance. Cretaceous Research, 88, 197-209. https://doi.org/10.1016/j.cretres.2017.10.009 
[10] Li, G. and Yang, Q. (2003) Confirmation of an Early Cretaceous Age for the Qihulin Formation in Eastern Heilongjiang Province, China: Constraints from a New Discovery of Radiolarians. Cretaceous Research, 24, 691-696.

https://doi.org/10.1016/j.cretres.2003.07.004

[11] Li, G. and Yu, S.M. (2004) Discovery of Agglutinated Foraminifers from the Longzhaogou Group in Eastern Heilongjiang Province. Science in China Series D: Earth Sciences, 47, 122-127. https://doi.org/10.1360/02yd0156 